\title{
The Incidence of the Corporate Income Tax on Wages: Evidence from Canadian Provinces
}

\author{
Kenneth J. McKenzie and Ergete Ferede*
}

April 2017

\begin{abstract}
This paper investigates the effect of the corporate income tax (CIT) on wages using panel data for Canadian provinces. We find that the CIT has a statistically significant negative effect on wages through its adverse impact on the capital/labour ratio. The empirical results suggest that workers bear a significant part of the corporate tax in the form of lower wages. Under the standard assumption that the CIT base is unresponsive to changes in the tax rate, our estimates suggest that the reduction in aggregate wages associated with a $\$ 1$ increase in provincial corporate tax revenue due to an increase in the statutory CIT rate ranges from 95 Canadian cents for Newfoundland and Labrador to C $\$ 1.74$ for New Brunswick. Under the more reasonable assumption that the CIT base shrinks in response to an increase in the tax rate, the estimates range from $\mathrm{C} \$ 1.52$ for Alberta to $\mathrm{C} \$ 3.85$ for Prince Edward Island. The results are robust to various sensitivity checks.
\end{abstract}

JEL Classification: $\mathrm{H} 22 ; \mathrm{H} 25 ; \mathrm{H} 71 ; \mathrm{J} 31$

Keywords: tax incidence; corporate income tax; wages; capital-labour ratio.

${ }^{*}$ An earlier version of this paper was presented at the University of Calgary School of Public Policy conference Reforming the Corporate Tax in a Changing World: A Conference on the 20th Anniversary of the Report of the Technical Committee on Business Taxation, Toronto, June 15, 2016. We thank participants at the conference for useful comments. McKenzie: Department of Economics, University of Calgary, 2500 University Dr. NW, Calgary AB T2N 1N4, Canada, kjmckenz@ucalgary.ca; Ferede: Department of Economics, MacEwan University, City Centre Campus, 10700 - 104 Avenue, Edmonton AB T5J 4S2, FeredeE@macewan.ca 


\section{Introduction}

Corporate income tax (CIT) incidence is an important and somewhat contentious issue in tax policy discussions. Much of the focus in the literature concerns the allocation of the burden of the CIT between owners of capital and labour. Since income from capital tends to be concentrated with wealthier individuals, if the burden of the CIT falls largely on capital it increases the tax system's progressivity. On the other hand, if the tax is borne mostly by labour through lower wages, the CIT is less progressive. Despite the importance of this issue in policy discussions, empirical evidence is quite limited and the results are mixed; there is a particular dearth of empirical research on the incidence of corporate taxes in a Canadian setting.

According to theoretical open economy general equilibrium models, the burden of the CIT may partly, and possibly largely, fall on labour. In these models, an increase in the CIT reduces the return to capital, causing capital to leave the jurisdiction, which lowers the marginal product of labour and ultimately wages. Thus, the CIT can have a negative indirect effect on wages through its impact on labour productivity by way of its impact on capital. However, the magnitude of this effect depends critically on several modelling assumptions and parameter values related to the size of the country, the degree of capital mobility, the nature of competition in the output market, etc.

An emerging empirical literature investigates the effects of CIT on wages by way of this indirect transmission mechanism. Empirical studies in this vein include Hassett and Mathur $(2006,2015)$

for a cross-section of countries; Desai et al. (2007) and Felix $(2007,2009)$ for the U.S. They all find evidence in support of the relevance of the indirect channel using national aggregate data. Other studies, such as Carroll (2009) and Felix (2009) for the U.S., examine corporate tax incidence at the sub-national level, and find that a substantial amount of the burden of the CIT falls on workers. 
However, a recent study by Clausing (2013) using OECD data casts some doubt on the relevance of the indirect channel and the empirical results of some of the above studies.

Another strand of research has focused on an alternative channel whereby the CIT affects wages directly. In these models, firms earn economic rents due to imperfect competition and/or other market frictions. Firms and workers bargain over these rents, allowing workers to earn a premium over the value of their marginal product. If firms earn economic rents and bargain with workers over their distribution, then an increase in the corporate tax can affect wages directly by lowering the rents available for distribution. Again, the theoretical results can be sensitive to various modelling assumptions and the emphasis has been on empirically identifying the so-called direct effect. Studies in this vein include Felix and Hines (2009) for the U.S., Dwenger et al. (2011) and Fuest et al. (2015) for Germany and Arulampalam et al. (2012) for a cross-section of European countries. They tend to find some empirical support for the direct transmission mechanism, though estimates of the size of the effect vary.

In this paper, we undertake one of the few empirical investigations of the incidence of the CIT on wages using Canadian data. We focus on the indirect transmission mechanism of corporate taxes on wages. To this end, we estimate wage and capital/labour ratio equations simultaneously, using a panel of provincial data from 1981 to 2014. In our most preferred specification, we estimate that the elasticity of the real hourly wage rate with respect to the statutory CIT rate at the provincial level is - 0.107 ; thus, a one per cent increase in the provincial corporate income tax rate is associated with a 0.107 per cent reduction in the real hourly wage rate.

A common approach to assessing the impact of an increase in the CIT on wages is to calculate the impact on aggregate wages of raising one more dollar in corporate tax revenue. We use this approach to calculate the incidence of the CIT in Canada's 10 provinces implied by our elasticity 
estimate. Under the commonly employed assumption that the CIT base is insensitive to changes in the tax rate, our estimates suggest that a $\$ 1$ increase in corporate tax revenues due to an increase in the provincial statutory CIT rate reduces aggregate wages by from 95 Canadian cents in Newfoundland and Labrador to $\mathrm{C} \$ 1.74$ in New Brunswick. In an innovation to this approach, when we account for the fact that the CIT base shrinks in response to an increase in the tax rate, our estimates are significantly higher, ranging from $\mathrm{C} \$ 1.52$ for Alberta to $\mathrm{C} \$ 3.85$ for Prince Edward Island.

Our results provide empirical support in a Canadian setting for the indirect transmission mechanism highlighted in the open economy general equilibrium models of corporate tax incidence and suggest that workers bear a significant part of the corporate income tax liability in the form of lower wages. The empirical results are robust to various sensitivity checks and are within the range of values obtained in previous similar studies.

The remainder of the paper is organized as follows. In section 2, we provide a brief overview of the literature on the incidence of the CIT. In section 3, we specify the empirical model and discuss the data. The empirical results are presented and discussed in section 4. Section 5 concludes.

\section{Literature Review}

Until relatively recently, research into the incidence of the CIT has been largely theoretical in nature. Harberger (1962) is often cited as the seminal paper in this regard. He investigated the incidence of the CIT in a closed economy general equilibrium setting. His analysis indicates that while, in principle, the incidence of the CIT could fall on either or both of capital and labour, plausible estimates of key parameters for the U.S. suggest that most of the burden of the CIT falls on capital. 
The insight that, under reasonable conditions, capital bears the bulk of this burden hinges critically on the assumption of a closed economy. More relevant for Canada and many countries has been the extension of general equilibrium models into an open-economy setting, which allows for the flow of goods and capital among jurisdictions. Extensions into an open-economy setting suggest that labour may bear a larger share of the corporate tax burden (Harberger, 1995, 2008; Grubert and Mutti, 1985; Gravelle and Smetters, 2006; Randolph, 2009), though there is some disagreement on the magnitude of that share. Gravelle (2013) provides a review of open economy general equilibrium incidence models, and concludes that the results hinge critically on key parameter values related to the degree of capital mobility, the competitiveness of the output market, the country's size, capital intensity and the substitutability of labour for capital, etc.

Although the theoretical simulation studies identify some of the key mechanisms by which the burden of the CIT may be transmitted to labour through lower wages, their policy relevance is perhaps limited by the inevitable underlying theoretical ambiguities and uncertainty over key parameter values. This has spawned a nascent empirical literature investigating the impact of corporate taxes on wages.

Hassett and Mathur (2006) conducted one of the first empirical studies of the impact of the CIT on wages using panel data for OECD countries. Their results suggest that a one per cent increase in the statutory corporate income tax rate leads to a decrease in average wages of about 0.95 per cent across different specifications in the long term. This paper received considerable attention and has spawned some criticism. Gravelle and Smetters (2006), for example, question both the robustness of their results and the plausibility of the magnitude of the estimates. In an updated study, Hassett and Mathur (2015) expand their analysis to include spatial effects, in particular controlling for tax rates in neighbouring countries. When controlling for spatial effects, they find that the impact 
of corporate taxes on wages is somewhat lower, but still very high, with a one per cent increase in the statutory tax rate leading to a decrease in wages of about 0.5 per cent. Although Hassett and Mathur (2015) do not explicitly identify the mechanism through which corporate taxes affect wages, their results are consistent with the indirect effect - corporate taxes lower the capital/labour ratio, which in turn lowers wages.

Desai et al. (2007) also investigate the indirect transmission mechanism using panel data on the foreign activities of U.S. multinationals. They explicitly examine the share of the corporate tax distributed between labour and capital, imposing the restriction that the shares add to one. Their estimates suggest that labour bears between 45 per cent and 75 per cent of the burden of corporate taxes levied on U.S. multinationals.

Carroll (2009) uses aggregate data from U.S. states from 1970 to 2007 to analyze the effect of CIT on wages at a sub-national level. He includes fixed and time effects, and controls for the degree of unionization and right-to-work laws, as well as various demographic factors. He generally finds a statistically significant effect of corporate taxes on the average real hourly earnings for production workers. In particular, a one per cent increase in the average state and local tax rate lowers real wages by 0.014 per cent. Using this estimate, he calculates that a $\$ 1$ increase in state and local corporate tax revenue results in a reduction in aggregate wages of roughly $\$ 2.50$.

Felix (2007) uses household survey data on wages for 30 countries from 1979 to 2002. This allows her to investigate the impact of corporate taxes on individuals in different skill groups. She finds that a one percentage point increase in the marginal corporate tax rate reduces wages by 0.7 per cent, and that those reductions are shared relatively equally across skill groups. This is a perhaps implausibly large effect, suggesting that the decrease in wages is more than four times the amount of corporate tax revenue collected. In a related study, Felix (2009) employs individual 
data at the U.S. state level for the period 1977-2005. She regresses wages on state-level corporate taxes. She finds that a one percentage point increase in the state marginal corporate tax rate reduces wages from 0.14 to 0.36 per cent.

Clausing (2013) takes a similar approach to Hassett and Mathur (2006, 2015), focusing on identifying the indirect channel by way of the capital/labour ratio. Using data on OECD countries from 1981 to 2009 , she takes a two-stage approach, first regressing the capital/labour ratio on various CIT measures (and controls), and then regressing wages on the capital/labour ratio (and controls). In the first-stage regressions relating the capital/labour ratio to the CIT, she finds no impact - the tax coefficients are statistically indistinguishable from zero. While she does find that the capital/labour ratio is positively correlated with higher wages in the second-stage regression, the lack of association between higher taxes and capital in the first stage causes her to question the indirect transmission mechanism identified in the open economy general equilibrium models.

More recently, studies such as Felix (2009), Riedel (2011), Arulampalam et al. (2012), Liu and Altshuler (2013) and Fuest et al. (2015) investigate an alternative channel whereby the CIT can affect wages directly. In these models, firms earn economic rents due to imperfect competition and/or other market frictions, and firms and workers bargain over these rents. The CIT reduces the rents available for distribution and can lead directly to a reduction in wages.

Felix and Hines (2009) investigate the impact of U.S. state-level corporate taxes on the union wage premium. They undertake a cross-sectional analysis on data from 2000, using state-level variation in wages, corporate taxes and the difference between union and non-union wages. Thus, they identify the CIT's direct effect by way of the union wage premium. Controlling for observable worker characteristics, they find that a one per cent lower state corporate tax rate is associated with a 0.36 per cent higher union wage premium. This suggests that a fully unionized firm captures 
roughly 54 per cent of the benefits of lower tax rates.

Arulampalam et al. (2012) employ micro firm-level data from nine European countries from 1999 to 2003, exploiting both within-firm and cross-firm variation in corporate taxation. Their specifications include firm- and time-fixed effects and incorporate dynamics via adjustment lags. As they control for firm value added (and therefore, indirectly, investment) their estimates can be viewed as identifying the direct effect of corporate taxes on wages. Their preferred estimate of the long-term elasticity of the direct effect on wages with respect to the corporate tax rate is -0.093 . They calculate that a $\$ 1$ increase in corporate taxes would reduce aggregate wages by 49 cents.

Liu and Altshuler (2013) also estimate a model of corporate income tax incidence at the U.S. state level. They allow for imperfect competition, which generates economic rents that can be shared between the firm and workers; they thus emphasize the direct channel and control for industry concentration ratios. They use data on individual workers matched with industry- and statespecific marginal effective tax rates and concentration ratios. They estimate a mean elasticity of wages with respect to the industry marginal effective tax rate of about -0.03 . This translates into a 60-cent reduction in aggregate wages associated with a $\$ 1$ increase in corporate tax liability.

Dwenger et al. (2011) use industry- and region-level data in Germany to identify the direct effect of corporate taxes. They use average tax rates (the average share of pre-tax profits paid in taxes), which they instrument for using calculations from a micro-simulation model. Another innovation in their study is to account for employment effects, which they find lower the impact of the corporate tax on wages. Nonetheless, they find that corporate taxes reduce wages, though by a relatively small amount: a $€ 1$ increase in corporate taxes lowers aggregate wages by 44 Eurocents.

Fuest et al. (2015) also focus on the direct effect using firm-level data for German municipalities, which have local autonomy with respect to setting local business tax rates. They employ 
an event study/difference-in-differences approach using 18,000 tax reforms over a 20-year period. Their results suggest that labour bears between 40 per cent to 50 per cent of the burden of corporate taxes. They also investigate the importance of various institutional features. For example, they find that wage responses are more negative for firms under collective bargaining agreements.

In a recent working paper aus dem Moore (2016) investigates the direct transmission mechanism using firm level data on companies in France and England. He estimates that in the long run a $€ 1$ increase in corporate taxes in France lowers aggregate wages in the manufacturing sector by 66 Eurocents; for England his results suggest an incidence of 77 pence. He also investigates various sources of firm-level heterogeneity on incidence, such as differences in firm size, average level of profitability, the degree of competition, and the sector firms operate in.

Ebrahimi and Vaillancourt (2016) use Canadian household data from 1998 to 2013 to examine the effects of corporate income taxes and payroll taxes on wages. They control for various individual characteristics as well as provincial fixed and time effects. They find that corporate taxes have an impact on wages even in the very short term, with a one per cent increase in the CIT rate reducing real wages by between 0.15 and 0.24 per cent.

On the whole, our reading of the emerging empirical research and the theoretical literature that underlies it, suggests that the evidence is building that some, and perhaps a great deal, of the burden of the CIT is borne by labour in the form of lower wages, both directly and indirectly, particularly in small open economies. However, the empirical research is relatively new, there is considerable variation in the estimates and studies using data from other jurisdictions are lacking.

Canada provides a useful laboratory in this regard because it is a prototypical small open economy and capital is very mobile both internationally and interprovincially (Helliwell and McKitrick, 1999; Bayoumi and Klein, 1997; Gouedard and Vaillancourt, 2011). Moreover, Canadian 
provinces share common institutional characteristics and are subject to a common interest and exchange rate regime.

\section{Empirical Specification and Data}

\subsection{Theoretical Framework}

In this section, we present a very simple model to illustrate the basic idea behind the indirect channel through which the CIT may be passed on to labour in an open economy, which will motivate our empirical approach. Consider a small open economy where output and capital are perfectly mobile interjurisdictionally, labour is immobile, and output and factor markets are perfectly competitive. The profits of the representative firm in the small open economy are:

$$
\Pi=F(K, L)-w L-r K-T
$$

where $F(K, L)$ is the production function, $K$ the amount of capital, $L$ the amount of labour, $w$ is the wage rate, $r$ is the net-of-tax user cost of capital. Corporate income taxes, $T$, are given by:

$$
T=t(F(K, L)-w L-\alpha r K
$$

where $t$ is the statutory CIT rate. Labour costs $(w L)$ are fully deductible for tax purposes, while a portion $\alpha \geq 0$ of capital costs $(r K)$ are deductible; this is intended to capture, in a highly stylized manner, features of many corporate tax systems. In principle, $\alpha$ can be less than or greater than one. The typical case would be $\alpha<1$, in which case the full costs of capital are not deductible. This may be the case, for example, due to the non-deductibility of the opportunity cost of equity finance and/or the less than full deduction of the economic costs of depreciation. However, $\alpha>1$ can 
occur if the tax system subsidizes capital, for example due to accelerated depreciation, investment allowances, investment tax credits, etc. If $\alpha=1$, the full opportunity cost of capital is deducted for corporate tax purposes and the corporate tax is a tax on economic profits or rents.

Substituting (2) into (1), profit maximization requires choosing capital and labour such that $d \Pi / d K=0$ and $d \Pi / d L=0$, which gives the first-order conditions:

$$
\begin{gathered}
F_{K}=r(1-\alpha t) /(1-t) \\
F_{L}=w
\end{gathered}
$$

where $F_{K}$ is the marginal product of capital and $F_{L}$ is the marginal product of labour.

For concreteness, say that output is determined by a constant returns to scale Cobb-Douglas production function, $F(K, L)=A K^{\beta} L^{1-\beta}$, where $0<\beta<1$ measures capital's share of output in the economy. Using the Cobb-Douglas formulation, after some re-arrangement (3) and (4) can be written as:

$$
\begin{gathered}
\frac{K}{L}=\left[\frac{\beta A}{r(1+\tau)}\right]^{1 /(1-\beta)} \\
w=(1-\beta) A\left(\frac{K}{L}\right)^{\beta}
\end{gathered}
$$

where $(1+\tau)=(1-\alpha t) /(1-t)$, and $\tau$ can be interpreted as the marginal effective tax rate (METR) on capital. Note that for $\alpha<1$, which is the typical case, $\tau>0$ and the METR increases with increases in the statutory CIT rate $t$. To close the model, assume for simplicity that labour is inelastically supplied (thus $L$ in (5) and (6) is fixed), ${ }^{1}$ and note that in a small open economy with perfect capital mobility the net-of-tax cost of capital $r$ is fixed by international markets. In this case, in equations (5) and (6), $K / L$ is the equilibrium capital/labour ratio and $w$ is the equilibrium

\footnotetext{
${ }^{1}$ This is for simplicity only; it is straightforward to allow for elastic labour supply.
} 
wage rate.

Several observations will prove useful in the subsequent discussion. First, from (5) it is evident that $K / L$ decreases as the METR on capital $(\tau)$ increases. This is because an increase in the tax on capital causes capital to move out of the small open economy to lower-taxed jurisdictions where it can earn the given net-of-tax return $r$. Moreover, from (6) we see that the equilibrium wage rate, $w$, is increasing in $K / L$. This is because as capital increases, labour becomes more productive, leading to an increase in the wage rate; of course, the opposite is true as well - the wage rate declines with $K / L$ as capital leaves the economy due to a decline in the marginal productivity of labour. Thus, for the typical case where $\alpha<1, K / L$ declines in response to an increase in the CIT, the marginal productivity of labour is lowered, causing the wage rate to fall. It bears mentioning that the opposite is true for the case where capital is subsidized $(\alpha>1)$. Also, as Auerbach (2005) and Fuest et al. (2015) have pointed out, if the CIT constitutes a tax on pure profits, or economic rent, with $\alpha=1$, an increase in the tax rate will impose no distortion on capital and would be borne entirely by shareholders. ${ }^{2}$

This is clearly a very simple model; it is provided simply to emphasize the key transmission mechanism and to motivate our subsequent empirical analysis. ${ }^{3}$ While it is possible to expand the model to allow for imperfect capital mobility, some degree of labour mobility across jurisdictions and imperfect competition in the output market, etc., ${ }^{4}$ the indirect channel through which the

\footnotetext{
${ }^{2}$ Though it is possible in this case that labour will bear some of the burden by way of the direct transmission mechanism.

${ }^{3}$ While we employ a Cobb-Douglas specification for concreteness, the basic results hold for any constant returns to scale production function. For the general case, equations (5) and (6) can be written as: $F_{K}(K, L)=r(1+\tau)$ and $F_{L}(K, L)=w$. If $F(K, L)$ is homogenous of degree 1 in $K$ and $L$ (as under constant returns to scale), then $F_{K}$ and $F_{L}$ are homogenous of degree zero, which gives $F_{i}(\lambda K, \lambda L)=F_{i}(K, L)$, for $\lambda>0, i=K, L$. Letting $\lambda=1 / L$, this gives $F_{K}(K / L, 1)=r(1+\tau)$ and $F_{L}(K / L, 1)=w$, which implicitly determine the equilibrium $K / L$ ratio as a function of $\tau$ and the wage rate in turn as a function of $K / L$.

${ }^{4}$ See Gravelle (2013).
} 
burden of CIT is thought to be transmitted to labour in a small open economy - by way of the capital/labour ratio - remains the same. Ultimately, it is an empirical matter as to how big that effect is.

\subsection{Empirical Specification}

To begin, consider Figures 1-3. Figure 1 is a scatter plot of the capital/labour ratio (y-axis) against the combined federal/provincial CIT rate (x-axis) for all provinces from 1981 to 2014, measured in logs. The plot shows a negative relationship between the two variables, which is consistent with the idea that higher corporate taxes are associated with lower capital/labour ratios. The existence of distinct groups in the figure suggests the presence of province- and/or time-specific fixed effects that will need to be accounted for in subsequent estimations. Figure 2 plots average hourly wages (y-axis) against the capital/labour ratio (x-axis). We see the expected positive relationship and, again, some suggestion of the presence of fixed effects. Finally, Figure 3 plots the average hourly wage rate (y-axis) directly against the CIT rate; we see a negative correlation, which is consistent with the notion that higher corporate tax rates are associated with lower wages. Of course, these simple correlations do not imply causation, and to examine fully the effect of corporate income tax rates on wages it is necessary to undertake a more rigorous empirical investigation.

Our empirical strategy, motivated by equations (5) and (6), and following in part Clausing (2013) and Hassett and Mathur (2015), involves the simultaneous estimation of the following two equations:

$$
\begin{aligned}
& \log (K / L)_{i t}=\alpha_{10}+\alpha_{11} \log (C I T)_{i t}+\alpha_{12} X_{i t}+\mu_{i}+\theta_{t}+u_{i t} \\
& \log (\text { Wage })_{i t}=\alpha_{20}+\alpha_{21} \log (K / L)_{i t}+\alpha_{22} Z_{i t}+\mu_{i}+\theta_{t}+\varepsilon_{i t}
\end{aligned}
$$


where $\log (K / L)_{i t}$ is the $\log$ of capital/labour ratio in province $i$ in year $t, \log (C I T)_{i t}$ is the $\log$ of the combined provincial and federal statutory CIT rate, and $\log (\text { Wage })_{i t}$ is the log of real hourly wage rate. $X$ and $Z$ are vectors of control variables that are thought to be important in explaining the capital/labour ratio and wage rate, respectively. This specification allows us to exploit both time-series and cross-sectional variation in wages and corporate taxes across provinces. As discussed above, provincial fixed effects, denoted by $\mu_{i}$, are included to account for unmeasured time-invariant province-specific factors that may affect differences in wage rates and capital/labour ratios across the provinces; we also include time effects, $\theta_{t}$, to control for common factors across provinces over time, such as business cycle conditions and other relevant policy changes at the national level. The corresponding error terms in the two equations are denoted by $u_{i t}$ and $\varepsilon_{i t}$. Our primary coefficients of interest are $\alpha_{11}$ and $\alpha_{21}$, the elasticity of $K / L$ with respect to CIT rate and the elasticity of the wage rate with respect to $K / L$ respectively.

As is well known, fixed effects estimation can be seen as a generalization of the difference-indifferences approach, extended to account for multiple treatment periods and groups (in our case provinces), and differing treatment intensities (in our case CIT rates). Identification is achieved by within group time variation (i.e., group specific changes over time); changes common to all groups are captured by the time fixed effects and are therefore not a source of variation in the identification of the treatment effects. As with differences-in-differences, the key underlying identification assumption is that, after controlling for other factors (captured in $X$ and $Z$ ), the trend in the dependent variables $(K / L$ and $w)$ would be the same in all groups in the absence of the treatments. Our use of Canadian provincial panel data, perhaps arguably, renders this assumption more tenable than would be the case for cross country data.

According to the open-economy model of corporate tax incidence, we would expect the CIT 
to have a negative impact on the capital/labour ratio, and the capital/labour ratio to in turn have a positive impact on the wage rate; thus we would expect $\alpha_{11}<0$ and $\alpha_{21}>0$. If this prediction holds, then we can compute the implied indirect effect of the CIT rate on wages using the estimated coefficients from the two equations as $\alpha_{11} * \alpha_{21}$, which is the elasticity of the wage rate with respect to the CIT rate; we would expect $\alpha_{11} * \alpha_{21}<0$.

Our empirical methodology involves the simultaneous estimation of equations (7) and (8). This approach has two advantages. First, note that $K / L$ is a dependent variable in equation (7) and an independent variable in equation (8). Ignoring the endogeneity of $K / L$ in equation (8) can lead to biased estimates. Also, the error terms may be contemporaneously correlated, which means that we can gain efficiency by estimating the two equations jointly.

Our key variable of interest in equation (7) is the corporate income tax rate $(\log (C I T))$. Since the capital stock takes time to adjust, we expect tax rates to have lagged effects on capital accumulation. Ideally, we would like to use a distributed lag model by including both contemporaneous and lagged values of the tax rate as explanatory variables to shed light on both the short-term and long-term effects of $C I T$ on capital stock and wage rate. However, due to the presence of strong multicollinearity among the lagged values of the CIT rate, precise estimates of short-term effects of $C I T$ on the wage rate cannot be obtained through such an approach, although this will not affect estimates of the tax rate's long-term effects. Thus, in our analysis, following both Clausing (2013) and Hassett and Mathur (2015), our measure of the tax rate is constructed as the average of the current and previous five years provincial and federal combined statutory corporate income tax. As Auerbach (2005) points out, such an approach also helps reduce the potential policy endogeneity of the corporate income tax rate. Because of the way the tax rate variable is constructed, the coefficient estimate can be interpreted as the long-term effect of the CIT rate on the capital/labour 
ratio. $^{5}$ Obviously, the choice of the lag length is ad hoc, although five-year lags are commonly used. Below, we undertake sensitivity tests to check the robustness of the results to the use of different lag lengths and to alternative definition of tax rates.

As indicated above, previous studies suggest that capital is highly mobile across Canadian provincial borders. Capital accumulation in one province may therefore be influenced not only by the corporate income tax rate in that province but also by the tax rates of neighbouring provinces. Thus, following Hassett and Mathur (2015), we include the log of the weighted average (weighted by GDP) corporate income tax rate of other provinces (otherCIT) as an explanatory variable. This specification allows the CIT and otherCIT to have differential effects on capital accumulation. Note also that otherCIT is constructed in the same way as CIT; that is, it is the average of the current and previous five-year values of the variable. Other things remaining the same, an increase in other provinces' tax rates should encourage capital to flow from high-tax provinces to low-tax provinces. Thus, we expect the coefficient on the log of otherCIT to be positive.

Capital accumulation may be thought to be higher in richer provinces than poorer ones. To account for this, following Clausing (2013), we include the contemporaneous value of the $\log$ of GDP per capita as an explanatory variable in the capital/labour ratio equation. ${ }^{6}$ We expect the coefficient on the log of GDP per capita to be positive. Further, the business environment in a jurisdiction and the associated private investment can be influenced by the governing party's ideological orientation. To control for the effect of ideology, we include a dummy variable that is equal to one if the provincial government belongs to the left-leaning New Democratic Party

\footnotetext{
${ }^{5}$ This approach is equivalent to using a distributed lag model with equal weights.

${ }^{6}$ If capital accumulates from domestic savings, an argument may be made for using lagged rather than contemporaneous GDP in this regard. The use of contemporaneous GDP is consistent with the small open economy setting whereby there is no correlation between domestic capital accumulation and savings, which finds empirical support for Canadian provinces in Helliwell and McKitrick (1999) and Gouedard and Vaillancourt (2011).
} 
(NDP). ${ }^{7}$ We expect this variable to have a negative effect on the capital to labour ratio.

The dependent variable in equation (2), $\log (\text { Wage })_{i t}$, is based on the average annual hourly earnings for all workers in all industries. The nominal values are converted into real wages using the Consumer Price Index (CPI) $(2007=100)$. As workers working overtime usually command higher wage rates, including overtime payments may distort the workers' actual hourly earnings. Thus, we exclude overtime payments from the hourly earnings. However, as part of the sensitivity analysis, we later check the robustness of our results to the inclusion of overtime payments. Ideally, as in Ebrahimi and Vaillancourt (2016), we would like to use the wage rate of workers employed in the private sector as our dependent variable. However, these data are not available at the aggregate level for Canadian provinces. Therefore, our wage rate data include the wages of those workers who work both in the private and public sectors. If higher corporate income tax revenue enables governments to raise wage payments for public sector workers, our CIT rate coefficient estimate may be biased. To address this, we include average real monthly wages and salaries per worker in the public sector (publicwages) as an additional control variable. We expect the coefficient on the $\log$ of public wages to be positive in the wage rate regression.

In our basic wage rate regressions, we control for other variables that are generally thought to have effects on wage rate and labour market outcomes. As is common in the related literature (Carroll, 2009), we include the share of workers who are unionized (union) as a control variable in the wage regression. As discussed above, unionized workers may be able to obtain higher wages and benefits through their collective bargaining power. This in part controls for the direct transmission mechanism discussed above, and is consistent with our focus on the indirect effect. We expect the coefficient on the union variable to be positive in the wage rate regression.

\footnotetext{
${ }^{7}$ Following the common classification in the related literature, the Parti Qubcois in Quebec and the Saskatchewan Party in Saskatchewan are categorized as NDP and Conservative, respectively.
} 
Higher education is often associated with higher wages. Thus, as in Carroll (2009), we also include the share of the population with a university degree (university) as an explanatory variable in the wage rate regression. If higher education increases labour productivity and raises wage rates, we expect the coefficient on log of university to be positive.

Personal income taxes may also affect the wages workers receive. To the extent that labour supply is not perfectly inelastic, or labour demand perfectly elastic, some of the burden of personal income taxes will fall on employers, and be reflected in the gross of tax wage rate. As such, we include the log of provincial and federal combined average effective personal income tax rate as a co-variate in the wage equation. ${ }^{8}$ We expect this variable to have a positive effect on gross-ofpersonal tax wages.

In addition, to control for labour market conditions, we include the log of current unemployment rate and the average labour growth rate. ${ }^{9}$ As in Clausing (2013), we use the average growth rate of labour over the previous five years to capture labour market conditions. We also use the average growth rate of the economy over the previous five years (AverageGDPgrowth) to account for the effect of macroeconomic conditions on wage rate. Again, this approach should reduce potential endogeneity problems with the relevant variables.

\subsection{Data}

We employ annual panel data from the ten Canadian provinces over the period 1981 to 2014 . The statutory top CIT rates were obtained from various issues of Finances of the Nation (formerly National Finances) published by the Canadian Tax Foundation. The data on all other variables

\footnotetext{
${ }^{8} \mathrm{As}$ is common in the literature, this variable is obtained by dividing total provincial and federal personal income tax revenue by total provincial taxable income.

${ }^{9}$ Labour growth is the growth rate of the total number of people in the labour force.
} 
in our analysis are obtained from Statistics Canada's database (CANSIM). Table 6 provides the definitions and sources of data for the different variables in more detail.

Table 1 provides information on our key variables of interest, the hourly wage rate and statutory CIT rates, for all provinces. To shed some light on the evolution of these key variables, we present the values at the initial, middle and final years of the sample period. We also present mean values of the variables over the whole sample period.

The average real hourly wage rate for all the provinces during the sample period was about $\mathrm{C} \$ 17.53$. Note that there is considerable variation in the mean hourly wage rate, ranging from $\mathrm{C} \$ 14.26$ for Prince Edward Island to $\mathrm{C} \$ 20.27$ for Alberta. During the period under consideration, the combined provincial and federal statutory corporate income tax rate averaged about 41.26 per cent. As Table 1 shows, there is significant variation in the corporate income tax rate across provinces. The period's average combined provincial and federal CIT rate ranges from 36.06 per cent in Quebec to about 42.88 per cent in Nova Scotia. There is also considerable variation in the statutory corporate income tax rates across provinces during the period, varying from 8.86 per cent in Quebec to 15.68 per cent in Nova Scotia. There has been generally a downward trend in the statutory provincial and federal combined corporate income tax rate due mainly to the reductions in the federal CIT rate over the sample period. Table 2 provides descriptive summary statistics of the other variables used in the empirical analysis.

\section{Empirical Results and Discussion}

\subsection{Empirical Results}

Table 3 presents the empirical results. Note again that we estimate the models including provincial fixed effects to account for unobserved province-specific factors that can influence the cap- 
ital/labour ratio and wages, and year-specific dummies to capture the effects of shocks that are common to all provinces. We focus our discussion on the coefficients on the main variables of interest.

In column 1 of Table 3 we estimate equations (7) and (8) separately by simple OLS, which does not take simultaneity into account. The coefficient on $\log (C I T)$ in the capital/labour ratio equation is negative and statistically significant at the one per cent level. Further, the coefficient on $\log (K / L)$ in the wage rate equation is positive and statistically significant at the one per cent level. Taken together, this is consistent with the prediction of the open economy general equilibrium model of indirect corporate income tax incidence. We compute the indirect effect of the corporate income tax rate on wages (through its effects on capital stock) using the estimated coefficient on $\log (C I T)$ in the $K / L$ equation and the estimated coefficient on $\log (K / L)$ in the wage rate regression. The product of these two coefficients is the implied effect of the corporate income tax rate on wages. Table 3 presents this estimate in the second to last row. This is our estimate of the elasticity of the real hourly wage rate with respect to the corporate income tax rate. The estimated elasticity of -0.107 is statistically significant at the one per cent level. It suggests that a one per cent increase in the corporate income tax rate is associated with a 0.107 per cent reduction in hourly wage rate.

As discussed above, the estimation of the two equations separately by OLS as reported in column (1) may not be appropriate, for two reasons. First, $\log (K / L)$ is a dependent variable in the capital/labour regression and is included as an exogenous independent variable in the wage regression. This means that the coefficient estimates may be biased. Secondly, the error terms in the two equations may be correlated.

With regard to the latter, the Breusch-Pagan test rejects the null of independence of residuals from the capital/labour ratio and the hourly wage rate equation at the five per cent level. Thus, we 
can gain efficiency by estimating the two equations jointly using the seemingly unrelated regression (SUR) method, as the error terms in the two equations are contemporaneously correlated. Joint estimation of the two equations will also help us obtain a more precise estimate of the wage rate's elasticity with respect to the corporate income tax rate. Column (2) of Table 3 presents coefficient estimates based on the SUR estimation method. The coefficient on $\log (C I T)$ remains negative and statistically significant at the one per cent level in the capital/labour ratio regression, and $\log (K / L)$ remains positive and significant at the one per cent level in the wage rate regression. The implied effect of corporate income tax rate on wages is negative and statistically significant, and the elasticity remains just under -0.11 .

So far, our analysis treats the $\log (K / L)$ in the wage regression as exogenous. However, as discussed above, since this is a dependent-variable first equation, this assumption may not be appropriate and can lead to biased results. To address this, we estimate equations (1) and (2) jointly by three-stage least squares (3SLS), which treats the $K / L$ ratio as endogenous and combines two-stage least squares with SUR (Wooldridge, 2002). This methodology is feasible because the two equations are over-identified. The results are given in column (3). This is our preferred specification. The coefficient on $\log (C I T)$ is, as expected, negative and statistically significant in the capital/labour ratio equation. Note that the coefficient on $\log (K / L)$ in the wage equation is now higher than the OLS result in column (1), and the SUR results in columns (2). This suggests that these estimates are biased downward, underestimating the impact of the capital/labour ratio on the wage rate.

The estimates in column (3) indicate that the elasticity of the capital/labour ratio with respect to the CIT rate is -0.233 , and that a one per cent increase in the CIT rate is associated with a 0.233 per cent decline in the capital/labour ratio. The coefficient on $\log (K / L)$ is also positive and 
statistically significant in the wage rate equation. In this case, the coefficient is now relatively higher, suggesting that not taking the endogeneity of the variable biases the coefficient estimate downwards. The estimated elasticity is 0.46 , which means that a one per cent increase in the capital/labour ratio is associated with a 0.46 per cent increase in the wage rate. The net result is an estimate of the elasticity of the real wage rate with respect to the corporate income tax rate of -0.107 , which is statistically significant at the five per cent level.

The foregoing analysis employs the statutory corporate income tax rate to capture the effects of the corporate income tax system. However, as shown in the simple model developed earlier, due to the presence of various tax credits and deductions, the effective tax burden corporations face may differ from the statutory tax rate. For this reason, some previous studies, such as Carroll (2009) and Hassett and Mathur (2015), use average and marginal effective tax rates as alternative tax measures of corporate taxes. Thus, we use the average effective tax rate $(A T R)$ and marginal effective tax rate (METR) in columns (4) and (5), respectively.

The average effective tax rate is computed as a ratio of the corporate income tax revenue that governments collect to a measure of the corporate tax base. Generally, obtaining an appropriate corporate tax base dataset is difficult and researchers often employ some form of proxy for the corporate income tax base. ${ }^{10}$ Fortunately, we were able to obtain administrative data from Finance Canada that give the corporate income tax base and tax revenue of all provinces for most of the period under consideration. The federal government uses these revenue and tax base data in its computation and allocation of equalization grants. Thus, in column (4) we use the average effective tax rate $(A T R)$ - which is computed as the ratio of corporate income tax revenue to corporate

\footnotetext{
${ }^{10}$ For example, Carroll (2009) uses the corporate income tax revenue to personal income ratio as average tax rate. However, Clausing (2013) and other later studies criticize the use of personal income as a proxy for corporate income tax base.
} 
income tax base - instead of the statutory corporate income tax rate. ATR is constructed as the average of the current and previous five years, as we have done for the statutory rate $(C I T)$. The results in column (4) show that, as expected, $A T R$ has a negative and significant effect on $\log (K / L)$, although in absolute value the numerical magnitude is lower. The estimated implied effect of the ATR on hourly wages is -0.045 and it is statistically significant at the five per cent level. The results suggest that a one per cent increase in the ATR is associated with a 0.045 per cent decrease in the real hourly wage rate.

In column (5), we use the marginal effective tax rate $(M E T R)$ as a measure of the effects of the corporate income tax system on hourly wages. Long time-series provincial data on the METR are not available. We use aggregate METR estimates from Chen and Mintz $(2006,2012)$ which are available only for the period 1997 to 2012 . This substantially reduces the number of observations available for estimation. The key variable in column (5) is $\log M E T R$. We also include the weighted average METR of other provinces (weighted by GDP) as an additional explanatory variable. Note that to minimize the potential endogeneity problem associated with the tax rate, we use five-year lag values of both the log of METR and the log of the weighted average METR of other provinces. ${ }^{11}$ The results indicate that corporate income tax as measured by the METR has a negative and statistically significant effect on the capital/labour ratio, which in turn has a statistically significant positive effect on hourly wages. The estimated implied elasticity of the METR on hourly wages is -0.037 and is statistically significant at the five per cent level, and again is lower than the estimates using the statutory CIT rate.

While the coefficients on the ATR and METR variables are negative and statistically significant - providing additional support for the indirect transmission mechanism of corporate taxes to wages

\footnotetext{
${ }^{11}$ Note that the method of constructing the METR variable is different from that used for statutory tax rates and ATR, dictated by the very limited number of observations for the variable.
} 
- the estimated elasticities are much lower than we obtain using the statutory CIT rate. This may be the case for a number of reasons. Statutory tax rate changes happen less frequently and when they occur it is because of an explicit policy choice. On the other hand, effective tax rates can change even if there are no tax policy changes. For instance, changes in economic conditions that affect corporate profits can result in changes in the ATR without any change in policy. The computation of METR requires various assumptions such as the type of investment, economic depreciation rates, discount rates, etc., all of which can change with economic conditions. There may therefore be some endogeneity issues associated with the use of these tax variables. Also, as indicated above, we have a very limited number of METR observations. Nonetheless, the results do provide additional empirical support to the open economy general equilibrium model of corporate income tax incidence using Canadian provincial data. Thus, regardless of the measure of corporate income rate employed in the analysis, the results suggest that corporate income taxes have a statistically significant negative effect on hourly wages and that some of the burden of the corporate tax falls on workers.

It may also be noted that the estimated coefficients on the control variables are generally consistent with our expectations. For example, in the $K / L$ regression, the coefficient on $\log ($ GDPpercapita) is positive and significant. Also noteworthy is the negative coefficient on the dummy variable for the presence of NDP governments, which is statistically significant. In the wage regressions, the average personal income tax rate variables are positive and significant, as expected. Moreover, the coefficients on labour growth, the unemployment rate, GDP growth, university enrolment and public sector wages are all the expected sign and statistically significant.

How do our results compare with those of earlier studies? As indicated previously, we use an empirical methodology similar to Clausing (2013). Unlike Clausing (2013), however, we find a 
statistically significant negative relationship between the corporate income tax rate and wages. Our results are also qualitatively robust to the use of alternative measures of corporate income tax rate. Our estimates of the elasticity of hourly wages with respect to the statutory corporate income tax rate are lower (in absolute value) than those of Hassett and Mathur (2006, 2015) and Felix (2007), but relatively close to the estimates of Carroll (2009) and Felix (2009). Notably, our elasticity estimates are also similar to Ebrahimi and Vaillancourt (2016), who also employ Canadian data.

\subsection{Corporate Tax Incidence Computations}

What do our results imply about the corporate income tax incidence on wages? Following the common practice in the literature, we measure the burden borne by labour by computing the reduction in aggregate wages associated with a $\$ 1$ increase in provincial CIT revenue (through an increase in the provincial statutory rate). We compute the corporate income tax incidence on wages for all ten provinces for the year 2014, which is the last year of our sample period. The computations

are based on the estimated wage elasticity with respect to the corporate income tax rate reported in column (3) of Table 3. We also use provincial corporate income tax revenue, total wage income in the private sector, and provincial and federal statutory CIT rates for 2014 in our calculations. Table 4 shows the results.

Previous studies tend to implicitly assume that the corporate tax base remains constant when the tax rate changes to calculate the corporate income tax incidence on wages. In order to compare our results to these studies, we begin by making a similar assumption in our computations, shown in column (1) in Table 4. For instance, for Alberta, total provincial corporate income tax revenue in 2014 was about $\mathrm{C} \$ 5.8$ billion. Thus, a 10 per cent increase in the provincial statutory corporate income tax rate, assuming that the tax base remains constant, leads to an increase in provincial 
corporate income tax revenue of $\mathrm{C} \$ 0.58$ billion. In the same year, total wage income in the private sector for the province was about $\mathrm{C} \$ 130.1$ billion. Given our elasticity estimate of -0.107 in column (3) of Table 3, a 10 per cent increase in the provincial statutory CIT rate, assuming that there is no impact on employment, leads to a decrease in aggregate wages in the private sector of about $\mathrm{C} \$ 0.557$ billion. ${ }^{12}$ This means that for each dollar of incremental corporate income tax revenue that the province collects due to an increase in its CIT rate, aggregate wages in the province fall by about 96 cents.

We do computations for other provinces in a similar fashion. Note that since we use the same wage elasticity estimate for all provinces, the variation in the computed corporate income tax incidence on wages across provinces is due to differences in the provincial statutory CIT rate, total provincial corporate tax revenue and total wage payments in the private sector. The results in column (1) show that for a $\$ 1$ increase in provincial corporate tax revenue through an increase in the provincial statutory CIT rate, the associated decrease in aggregate wages ranges from a low of 95 cents for Newfoundland and Labrador to a high of C $\$ 1.74$ for New Brunswick. ${ }^{13}$ This shows $^{2}$ that there is a significant variation in the effects of CIT on wages across the Canadian provinces.

How do these estimates compare with previous studies? For U.S. states, Felix (2009) and Carroll (2009) estimate the burden borne by labour of a $\$ 1$ increase in corporate tax liability to be between $\$ 1.40-\$ 3.60$ and $\$ 2.50$, respectively. Using cross-section data, Hassett and Mathur (2006) estimate the burden borne by labour to be between $\$ 22$ and $\$ 26$, which may be considered

\footnotetext{
${ }^{12}$ For 2014, Alberta's and the federal government's statutory CIT rates were 10 per cent and 15 per cent, respectively. Given our implied wage elasticity with respect to the CIT rate estimate of -0.107 and provincial total wages in the private sector of $\mathrm{C} \$ 130.1$ billion, the effect of a 10 per cent increase in the provincial CIT rate on wages is simply computed as: $0.10 *-0.107 *(0.10 /(0.10+0.15) *(C \$ 130.1$ billion $)=-C \$ 0.557$ billion.

${ }^{13}$ Note that in our panel regression analysis we control for other provinces' weighted average provincial CIT rate. Thus, our wage elasticity estimates (with respect to CIT rate) and all associated computations should be interpreted as the effect of an increase in the CIT rate by a province while all other provinces keep their CIT rates constant.
} 
unreasonably high. Their more recent estimate (Hassett and Mathur, 2015), however, indicates that labour's burden is about $\$ 13$. On the other end of the spectrum, Liu and Altshuler (2013) estimate the burden borne by labour to be 60 cents. As such, our computations are generally in line with previous studies.

As indicated above, to make our calculations comparable to previous studies the calculations in column (1) in Table 4 presume that the corporate tax base does not change in response to the increased tax rate. Dahlby and Ferede (2012) examine the sensitivity of the corporate income tax base to changes in provincial CIT rates. They estimate that, on average, a one percentage point increase in a provincial CIT rate causes the corporate tax base to shrink by 3.67 per cent in the short term, and 13.60 per cent in the long term. This means that an increase in a provincial CIT rate will raise less revenue than presumed in the previous computations, understating the impact of a $\$ 1$ increase in corporate taxes on labour. To account for the shrinkage in the CIT base in response to an increase in the tax rate, and in an innovation relative to previous approaches, we proceed as follows. Let $t_{p}$ and $t_{f}$ denote the provincial and federal CIT rates, respectively. As above, the product $\alpha_{11} * \alpha_{21}$ is the implied wage elasticity with respect to the CIT rate; let $\varepsilon_{c c}$ denote the CIT base semi-elasticity with respect to $t_{p}$. The effect of a one-dollar increase in the CIT revenue (through a change in $t_{p}$ ) on wages accounting for the shrinkage in the CIT base can then be computed as:

$$
\frac{\left(\alpha_{11} * \alpha_{21}\right) *\left(\frac{t_{p}}{t_{p}+t_{f}}\right)}{\left(1+t_{p} * \varepsilon_{c c}\right)} *\left(\frac{\text { TotalWages }}{\text { CITRevenue }}\right)=\left(\alpha_{11} * \alpha_{21}\right) *\left(\frac{t_{p}}{t_{p}+t_{f}}\right) * M C F_{p}
$$

where $M C F_{p}$ is the Marginal Cost of Public Funds for the CIT in province $p$.

In column 2 of Table 4, we take the shrinkage in the corporate tax base into account, using 
the semi-elasticity and associated MCF estimates in Dahlby and Ferede (2012). ${ }^{14}$ From column (2), which uses our elasticity estimates based on the statutory CIT rate, we see that the burden of the tax on labour is higher, ranging from $\mathrm{C} \$ 1.52$ for Alberta to $\mathrm{C} \$ 3.85$ for Prince Edward Island. Note that the change in the provinces' ranking occurs because the computation is sensitive to the statutory CIT rate; provinces with a lower CIT rate tend to have lower incidence on wages. ${ }^{15}$

\subsection{Robustness and Sensitivity Analysis}

Our calculations of the corporate income tax incidence on wages depend crucially on wage elasticity estimates. In this section, we conduct various robustness checks to investigate the sensitivity of our estimates. We analyze the robustness of our results to the choice of various lag lengths, the use of total capital stock instead of non-residential capital stock, to the inclusion of overtime payments in hourly wages, and to the inclusion of the relative price of capital as an additional control variable in the capital regression. Table 5 reports the results of the robustness checks. For the sake of brevity, we present only the coefficients of our variables of interest under the 3SLS specification. That is, we report the coefficient on $\log (C I T)$ in the capital regression $\left(\alpha_{11}\right)$ in column $(1)$, the coefficient on $\log (K / L)$ in the wage rate regression $\left(\alpha_{21}\right)$ in column (2), and the implied effects of $\log (C I T)$ on hourly wage rate $\left(\alpha_{11} * \alpha_{21}\right)$ in column (3).

As previously indicated, we use the average statutory CIT rate of the current and previous five years as our key tax variable. Although this approach can help minimize the potential endogeneity

\footnotetext{
${ }^{14}$ When a province raises its CIT rate (given the federal and other provinces' CIT rate), the tax base shrinks. This shrinkage in the tax base adversely affects the revenue that both the federal and the provincial governments collect in the province. The shrinkage of the tax base can be partly due to the mobility of the base to another jurisdiction. If the tax base shrinks due to the mobility of the base to another province, the fall in the federal government revenue in the tax-raising province may be compensated by the increase in the federal revenue from the other province (the province to which the base moves). Therefore, in our analysis, we assume that the increase in the provincial statutory CIT rate will not affect federal CIT revenue.

${ }^{15}$ It bears mentioning that our estimates and calculations might be considered a lower bound for the impact of the CIT on wages as they isolate the indirect effect and do not account for any direct effects.
} 
problem of the tax rate and address the expected lagged effects of tax rate changes on the capital stock, the choice of a five-year lag is ad hoc. In our sensitivity analysis, we experiment with alternative lag lengths for the tax rate. More specifically, we use: the average of the current and previous four years of the CIT rate (row (1)), the average of current and previous three years of the CIT rate (row (2)), contemporaneous and up to five-year lagged tax rates separately (row (3)), up to four-year lagged tax rates (row (4)), and up to three-year lagged tax rates (row (5)). In all cases, we find that the corporate income tax rate continues to have a statistically significant effect on wages through its adverse effect on the capital/labour ratio, suggesting that the results are robust to these changes.

Arguably, the capital stock most influenced by the corporate income tax is the non-residential capital stock (Parsons, 2008). However, some studies, such as Clausing (2013), use the total capital stock. Consequently, as part of our sensitivity analysis, we use the total capital stock to labour ratio in row (6). All the other variables are as defined and used in column (4) of Table 3. Compared to our preferred regression result, the effect of the CIT rate on the capital/labour ratio is lower in absolute value and the effect of the capital/labour ratio on the wage rate is higher. The net result of this is that the elasticity of the hourly wage rate with respect to the CIT rate is slightly higher in absolute value compared to our preferred result.

In row (7), we use the hourly wage rate including overtime payments. Again, our main results remain largely unaffected, although the numerical magnitudes of the coefficient estimates are now slightly higher. Finally, we include the log of the relative price of capital as an additional explanatory variable in our regression. Although our dependent variable is the capital/labour ratio, some previous studies that focus on the estimation of the elasticity of the user cost of capital, such as Shaller (2006) and Parsons (2008), include the relative price of capital in their analysis. Thus in 
row (8), we control for the log of the relative price of capital, defined as the ratio of the implicit price index of gross fixed capital formation to the implicit price index of GDP. Again, our main result that the corporate income tax rate and wages are negatively related through the adverse effect of the former on capital/labour ratio is robust.

Finally, in row (9), we include the provincial and federal CIT rates separately as explanatory variables. Since the federal CIT rate changes only over time, it is not possible to control for year effects in this regression. Nonetheless, the results show that both provincial and federal CIT rates have adverse effects on wages. The effect of the provincial CIT rate on wages is larger in absolute value. This is expected, as we would expect capital to be more mobile across provincial borders than internationally.

In sum, although the magnitudes of the coefficient estimates vary, our results are generally robust to various sensitivity checks. Our results indicate that higher corporate income tax reduces capital accumulation and the resulting reduction in the capital/labour ratio in turn reduces worker productivity and their hourly wages. The implication of this is that a significant part of the corporate income tax burden falls on workers in the form of lower wages.

\section{Conclusions}

Corporate income tax incidence is one of the more contentious issues in tax policy discussions. Since corporations are merely conduits through which income passes to individuals, it is not clear who ultimately bears the burden of corporate taxes. The issue has important implications for the overall fairness of the tax system and determination of the distribution of tax burdens across different factors, owners and income groups.

In this paper, we conduct an empirical investigation of the impact of corporate taxes on wages 
using panel data for Canadian provinces from 1981 to 2014. The theoretical basis for our empirical analysis is the general equilibrium open-economy model of corporate income tax incidence, which emphasizes the indirect channel to wages by way of the capital/labour ratio. As such, we estimate wage and capital/labour ratio equations simultaneously. Our empirical results indicate that the CIT rate adversely affects the capital/labour ratio, which in turn reduces wages; the implied elasticity of the average hourly wage rate with respect to the statutory CIT rate is -0.107 . The results are robust to various sensitivity checks and within the range of values obtained in previous similar studies.

We use the empirical estimates to compute the corporate income tax incidence for all the provinces for year 2014. Under the standard assumption in the literature which ignores the shrinkage in the CIT base, our computations suggest that for a $\$ 1$ increase in corporate tax revenue due to an increase in the provincial CIT rate, the associated decrease in aggregate wages ranges from 95 cents for Newfoundland and Labrador to $\mathrm{C} \$ 1.74$ for New Brunswick. When we take the shrinkage in the CIT base into account, the amount borne by labour is higher, ranging from $\mathrm{C} \$ 1.52$ for Alberta to $\mathrm{C} \$ 3.85$ for Prince Edward Island. 


\section{References}

Arulampalam, Wiji, Michael P Devereux, and Giorgia Maffini, "The Direct Incidence of the Corporate Income Tax on Wages,” European Economic Review, 2012, 56, 1038-1054.

Auerbach, Alan J, "Who Bears the Corporate Tax? A Review of What We Know," NBER Working Paper No. 11686, 2005.

aus dem Moore, Nils, "Shifting the Burden of Corporate Taxes - Heterogeneity in Direct Wage Incidence," Beitrge zur Jahrestagung des Vereins fr Socialpolitik 2016: Demographischer Wandel - Session: Corporate Taxes and Firm Behavior, 2016, No. B11-V1.

Bayoumi, Tamin and Michael W. Klein, “A Provincial View of Capital Mobility," International Monetary Fund Staff Papers, 1997, 44(4), 534-556.

Carroll, Roberts, "Corporate Tax and Wages: Evidence from the 50 States," Tax Foundation Working Paper No. 8, 2009.

Chen, Duanjie and Jack M. Mintz, "Federal/Provincial Combined Marginal Effective Tax Rates on Capital 1997-2006. Supplementary information for Business Tax Reform: More Progress Needed," C.D. Howe Institute e-brief, 2006.

_ and _ , "2012 Annual Global Tax Competitiveness Ranking - a Canadian Good News Story," SPP Research Paper, 2012, 5 (28). School of Public Policy, The University of Calgary, Calgary Canada.

Clausing, Kimberly A., "Who Pays the Corporate Tax in a Global Economy?," National Tax Journal, 2013, 66(1), 151-184.

Dahlby, Bev and Ergete Ferede, "The Effects of Tax Rate Changes on Tax Bases and the Marginal Cost of Public Funds for Canadian Provincial Governments," International Tax and Public Finance, 2012, 19, 844-883.

Desai, M., Fritz Foley, and James Hines, "Labor and Capital Shares of the Corporate Tax Burden: International Evidence.," 2007. Mimeo.

Dwenger, Nadja, Pia Rattenhuber, and Viktor Steiner, "Sharing the Burden: Empirical Evidence on Corporate Tax Incidence," School of Business \& Economics Discussion Paper: Economics, No. 2011/14, 2011.

Ebrahimi, P. and F. Vaillancourt, "The Effect of Corporate Income and Payroll Taxes on the Wages of Canadian Workers," Fraser Institute Research Paper, 2016.

Felix, Alison R., "Passing the Burden: Corporate Tax Incidence in Open Economies," Federal Reserve Bank of Kansas City Working Paper, 2007. 
_ , "Do State Corporate Income Taxes Reduce Wages?," Federal Reserve Bank of Kansas City Working Paper, 2009.

_ and James R. Hines, "Corporate Taxes and Union Wages in the United States," NBER Working Paper No. 15263, 2009.

Fuest, Clemens, Andreas Peichl, and Sebastian Siegloch, "Do Higher Corporate Taxes Reduce Wages?," IZA Discussion Paper No. 9606, 2015. The Institute for the Study of Labour, Bonn Germany.

Gouedard, P. and F. Vaillancourt, "Taux d'investissement prive et pargne des menages des provinces canadiennes, 1990-2008," Cirano Project Report 2011RP-14, 2011. Center for Interuniversity Research and Analysis of Organizations, Montreal Canada.

Gravelle, Jane G. and Kent A. Smetters, "Does the Open Economy Assumption Really Mean that Labor Bears the Burden of a Capital Income Tax?," The B.E. Journal of Economic Analysis \& Policy, Advances in Economic Analysis and Policy, 2006, 6(1).

- and Laurence J. Kotlikoff, "Corporate Tax Incidence and Inefficiency when Corporate and Non-Corporate Goods are Close Substitutes,” Economic Inquiry, 1993, 31(4), 501-516.

Gravelle, Jennifer, "Corporate Tax Incidence: Review of General Equilibrium Estimates and Analysis," National Tax Journal, 2013, 66(1), 184-214.

Grubert, Harry and John Mutti, "The Taxation of Capital Income in an Open Economy: The Importance of Resident-Nonresident Tax Treatment," Journal of Public Economics, 1985, 27(3), 291-308.

Harberger, Arnold C., "The Incidence of the Corporation Income Tax," Journal of Political Economy, 1962, 70(3), 215-240.

_, "The ABCs of Corporation Tax Incidence: Insights into the Open-Economy Case," in "Tax Policy and Economic Growth," Washington DC: American Council for Capital Formation, 1995.

_, "Corporate Tax Incidence: Reflections on what is Known, Unknown and Unknowable," in John W. Diamond and George R. Zodrow, eds., Fundamental Tax Reform: Issues, Choices, and Implications, Cambridge USA: MIT Press, 2008.

Hassett, Kevin A. and Aparna Mathur, “Taxes and Wages," American Enterprise Institute Working Paper No. 128, 2006. Washington DC.

_ and _, "A Spatial Model of Corporate Tax Incidence," Applied Economics, 2015, 47(13), $1350-1365$.

Helliwell, John and Ross McKitrick, "Comparing Capital Mobility Across Provincial and National Borders," Canadian Journal of Economics, 1999, 32(5), 1164-1173. 
Liu, Li and Rosanne Altshuler, "Measuring the Burden of the Corporate Income Tax Under Imperfect Competition," National Tax Journal, 2013, 66(1), 215-238.

Parsons, M., "The Effect of Corporate Taxes on Canadian Investment: An Empirical Investigation," Department of Finance Working Paper No. 2008-01, 2008. Department of Finance, Ottawa Canada.

Randolph, William C., "International Burdens of the Corporate Income Tax," Congressional Budget Office Working Paper 2006-09, 2009. Congressional Budget Office, Washington DC.

Riedel, Nadine, "Taxing Multinationals Under Union Wage Bargaining," International Tax and Public Finance, 2011, 18(4), 399-421.

Shaller, Huntley, "Econometric Issues in Estimating User Cost Elasticity," Economic Series 194, 2006. Institute for Advanced Study.

Wooldridge, Jeffrey, Econometric Analysis of Cross Section and Panel Data, Cambridge USA: MIT Press, 2002. 
Figure 1: Capital/Labour Ratios vs. Combined Federal/Provincial Statutory CIT Rates, All Provinces, 1981-2014

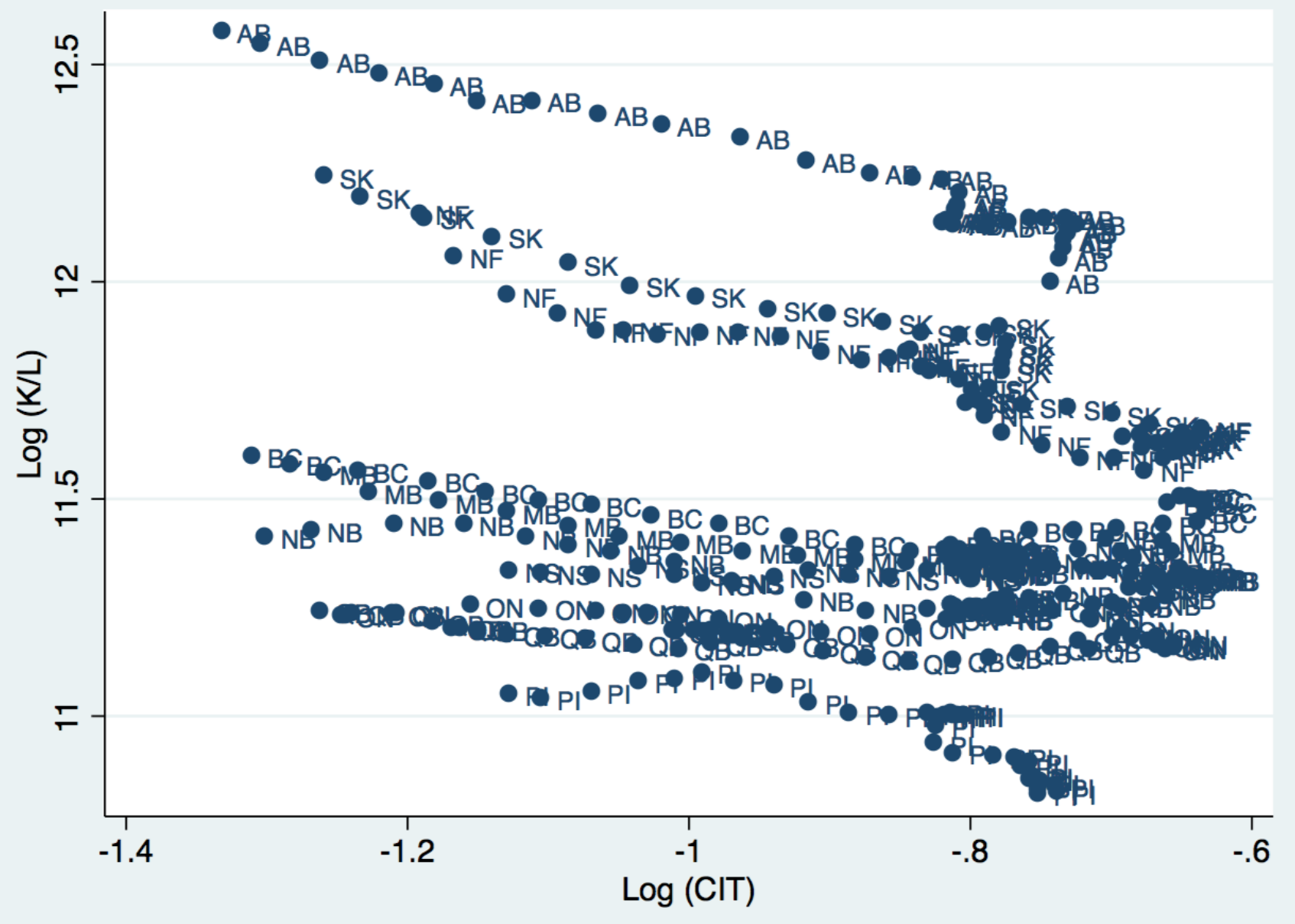


Figure 2: Average Hourly Wages vs. Capital/Labour Ratios, All Provinces, 1981-2014

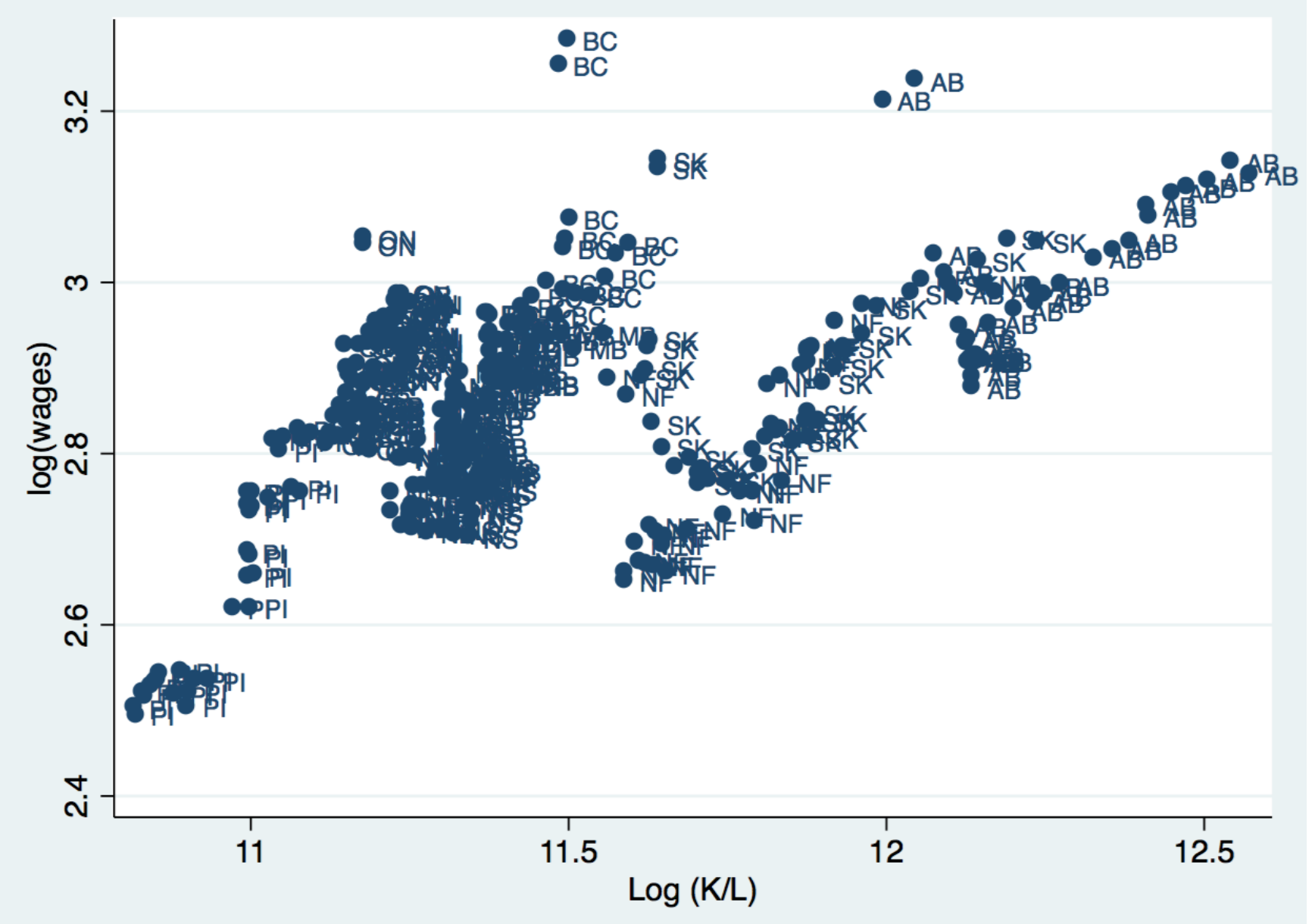


Figure 3: Average Hourly Wages vs. Statutory Combined Federal-Provincial CIT Rates, All Provinces, 1981-2014

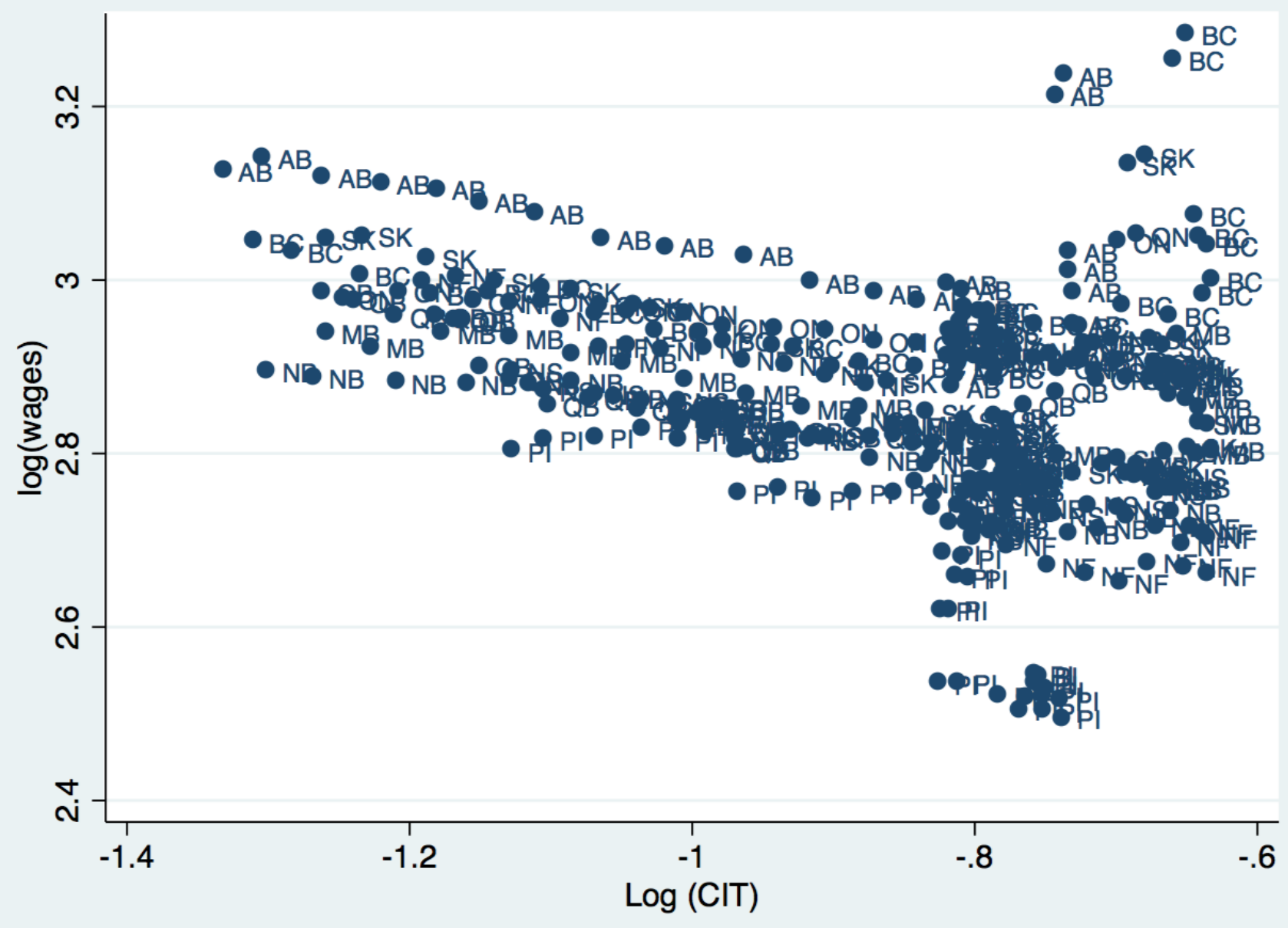


Table 1: Profile of Canadian Provinces, 1981-2014

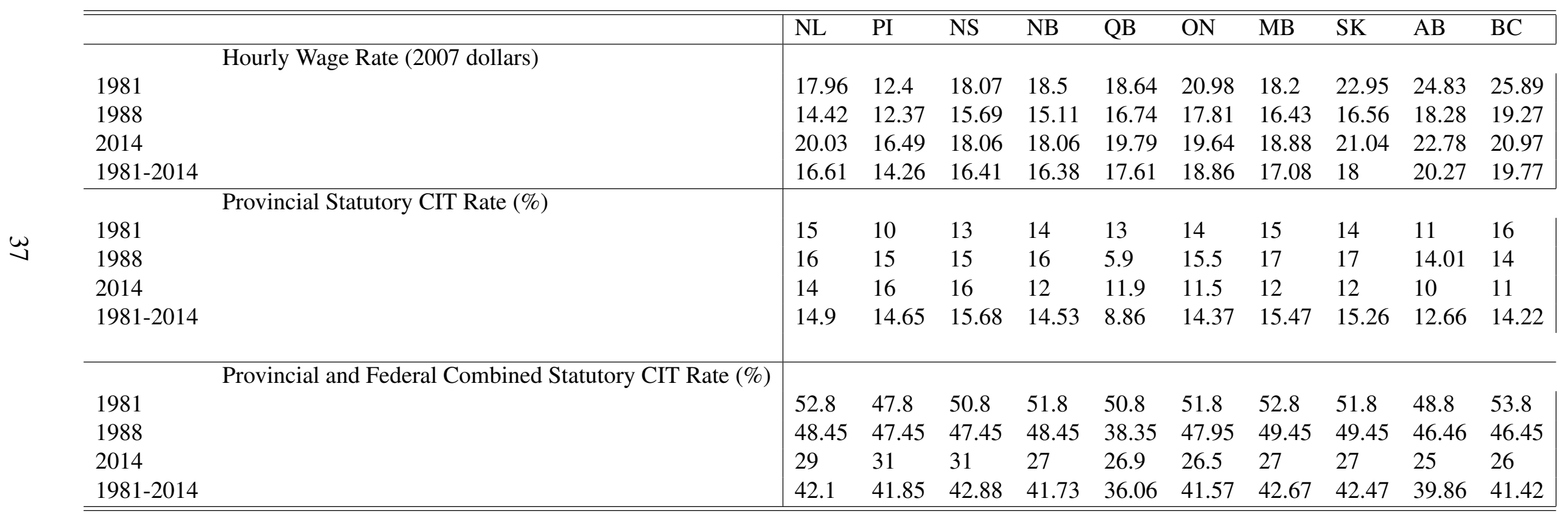

Source: Table 6; authors' calculations. 
Table 2: Summary Statistics

\begin{tabular}{|c|c|c|c|c|}
\hline Variable & Mean & Std. Dev. & Min & Max \\
\hline Hourly wage rate, 2007 dollars & 17.526 & 2.265 & 12.113 & 26.649 \\
\hline Provincial statutory CIT rate & 0.141 & 0.027 & 0.055 & 0.170 \\
\hline Combined statutory CIT rate $(\mathrm{CIT})^{\mathrm{a}}$ & 0.428 & 0.069 & 0.264 & 0.532 \\
\hline $\log (\mathrm{CIT})^{\mathrm{a}}$ & -0.905 & 0.205 & -1.386 & -0.601 \\
\hline $\log (A T R)^{a}$ & -1.192 & 0.200 & -1.679 & -0.464 \\
\hline $\log (\text { OtherCIT })^{\mathrm{a}}$ & -2.032 & 0.070 & -2.184 & -1.843 \\
\hline Log(wage) & 2.855 & 0.129 & 2.494 & 3.283 \\
\hline $\log (\mathrm{K} / \mathrm{L})$ & 11.462 & 0.369 & 10.818 & 12.573 \\
\hline Average labour growth rate ${ }^{b}$ & 0.014 & 0.010 & -0.014 & 0.067 \\
\hline Average GDP growth rate ${ }^{b}$ & 0.026 & 0.015 & -0.010 & 0.096 \\
\hline Log(GDP per capita) & 10.588 & 0.309 & 9.933 & 11.469 \\
\hline Log(unemployment) & -2.408 & 0.391 & -3.352 & -1.599 \\
\hline Log(university) & -2.301 & 0.413 & -3.440 & -1.469 \\
\hline $\log ($ union $)$ & 3.483 & 0.190 & 3.011 & 4.054 \\
\hline Log(openness) & 0.089 & 0.161 & -0.246 & 0.624 \\
\hline Log(public wages) & 37.581 & 3.223 & 31.576 & 49.211 \\
\hline NDP government & 0.221 & 0.415 & 0 & 1 \\
\hline $\log (\mathrm{PIT})$ & -1.488 & 0.138 & -1.756 & -1.028 \\
\hline
\end{tabular}

Note: The total number of observations is 340 .

a: These variables are the averages of the current year and previous five years.

b: These variables are the averages of the previous five years. 
Table 3: Regression Results, 1981-2014

\begin{tabular}{|c|c|c|c|c|c|}
\hline & $\begin{array}{l}\text { (1) } \\
\text { OLS }\end{array}$ & $\begin{array}{l}\text { (2) } \\
\text { SUR }\end{array}$ & $\begin{array}{l}\text { (3) } \\
\text { 3SLS }\end{array}$ & $\begin{array}{l}\text { (4) } \\
\text { 3SLS }\end{array}$ & $\begin{array}{l}\text { (5) } \\
\text { 3SLS }\end{array}$ \\
\hline \multicolumn{6}{|l|}{ Dependent variable: $\log (K / L)$} \\
\hline $\log (\mathrm{CIT})$ & $\begin{array}{l}-0.436^{* * * *} \\
(0.121)\end{array}$ & $\begin{array}{l}-0.355 * * * \\
(0.112)\end{array}$ & $\begin{array}{l}-0.233^{* *} \\
(0.11)\end{array}$ & & \\
\hline $\log (\mathrm{ATR})$ & & & & $\begin{array}{l}-0.069 * * \\
(0.028)\end{array}$ & \\
\hline $\log ($ METR $)$ & & & & & $\begin{array}{l}-0.116^{* * * *} \\
(0.033)\end{array}$ \\
\hline Log(Other CIT $)$ & $\begin{array}{l}-0.006 \\
(0.231)\end{array}$ & $\begin{array}{l}0.058 \\
(0.213)\end{array}$ & $\begin{array}{l}0.134 \\
(0.205)\end{array}$ & $\begin{array}{l}0.155 \\
(0.133)\end{array}$ & $\begin{array}{l}0.594 * * \\
(0.255)\end{array}$ \\
\hline Log(GDP per capita) & $\begin{array}{l}0.584 * * * \\
(0.055)\end{array}$ & $\begin{array}{l}0.622 * * * \\
(0.051)\end{array}$ & $\begin{array}{l}0.639 * * * \\
(0.05)\end{array}$ & $\begin{array}{l}0.625 * * * \\
(0.051)\end{array}$ & $\begin{array}{l}0.510 * * * \\
(0.105)\end{array}$ \\
\hline NDP government & $\begin{array}{l}-0.012 \\
(0.01)\end{array}$ & $\begin{array}{l}-0.016^{*} \\
(0.01)\end{array}$ & $\begin{array}{l}-0.020^{* *} \\
(0.009)\end{array}$ & $\begin{array}{l}-0.023 * * * \\
(0.008)\end{array}$ & $\begin{array}{l}-0.057 * * * \\
(0.011)\end{array}$ \\
\hline \multicolumn{6}{|l|}{ Dependent variable: Log(Wage) } \\
\hline $\log (\mathrm{K} / \mathrm{L})$ & $\begin{array}{l}0.245^{* * *} \\
(0.034)\end{array}$ & $\begin{array}{l}0.303 * * * \\
(0.031)\end{array}$ & $\begin{array}{l}0.461 * * * \\
(0.043)\end{array}$ & $\begin{array}{l}0.645^{* * *} * \\
(0.05)\end{array}$ & $\begin{array}{l}0.320 * * * \\
(0.116)\end{array}$ \\
\hline $\log (\mathrm{PIT})$ & $\begin{array}{l}0.269 * * * \\
(0.053)\end{array}$ & $\begin{array}{l}0.267 * * * \\
(0.048)\end{array}$ & $\begin{array}{l}0.257 * * * \\
(0.048)\end{array}$ & $\begin{array}{l}0.228 * * * \\
(0.048)\end{array}$ & $\begin{array}{l}0.004 \\
(0.038)\end{array}$ \\
\hline Average labour growth & $\begin{array}{l}1.133^{* *} \\
(0.45)\end{array}$ & $\begin{array}{l}1.066^{* * * *} \\
(0.41)\end{array}$ & $\begin{array}{l}0.937 * * \\
(0.406)\end{array}$ & $\begin{array}{l}0.838^{* *} \\
(0.4)\end{array}$ & $\begin{array}{l}0.66 \\
(0.453)\end{array}$ \\
\hline Average GDP growth & $\begin{array}{l}0.577^{* *} \\
(0.27)\end{array}$ & $\begin{array}{l}0.479^{*} \\
(0.247)\end{array}$ & $\begin{array}{l}0.484 * \\
(0.25)\end{array}$ & $\begin{array}{l}0.415^{*} \\
(0.251)\end{array}$ & $\begin{array}{l}0.334 * \\
(0.187)\end{array}$ \\
\hline Log(unemployment) & $\begin{array}{l}0.084 * * * \\
(0.02)\end{array}$ & $\begin{array}{l}0.083 * * * \\
(0.018)\end{array}$ & $\begin{array}{l}0.084 * * * \\
(0.018)\end{array}$ & $\begin{array}{l}0.082 * * * \\
(0.018)\end{array}$ & $\begin{array}{l}-0.024 \\
(0.015)\end{array}$ \\
\hline Log(university) & $\begin{array}{l}0.184 * * * \\
(0.041)\end{array}$ & $\begin{array}{l}0.168 * * * \\
(0.038)\end{array}$ & $\begin{array}{l}0.131 * * * \\
(0.038)\end{array}$ & $\begin{array}{l}0.095^{* *} \\
(0.038)\end{array}$ & $\begin{array}{l}0.039 \\
(0.052)\end{array}$ \\
\hline $\log$ (union) & $\begin{array}{l}0.029 \\
(0.038)\end{array}$ & $\begin{array}{l}0.043 \\
(0.035)\end{array}$ & $\begin{array}{l}0.052 \\
(0.035)\end{array}$ & $\begin{array}{l}0.054 \\
(0.034)\end{array}$ & $\begin{array}{l}-0.077 \\
(0.095)\end{array}$ \\
\hline Log(openness) & $\begin{array}{l}-0.028 \\
(0.039)\end{array}$ & $\begin{array}{l}-0.037 \\
(0.035)\end{array}$ & $\begin{array}{l}-0.057 \\
(0.035)\end{array}$ & $\begin{array}{l}-0.079 * * \\
(0.035)\end{array}$ & $\begin{array}{l}-0.008 \\
(0.053)\end{array}$ \\
\hline Log(public wages) & $\begin{array}{l}0.008 * * * \\
(0.002)\end{array}$ & $\begin{array}{l}0.008 * * * \\
(0.001)\end{array}$ & $\begin{array}{l}0.007 * * * \\
(0.002)\end{array}$ & $\begin{array}{l}0.007 * * * \\
(0.002)\end{array}$ & $\begin{array}{l}-0.001 \\
(0.002) \\
\end{array}$ \\
\hline Implied effect of CIT rate on wages & $\begin{array}{l}-0.107^{* *} \\
(0.033)\end{array}$ & $\begin{array}{l}-0.108^{* * *} \\
(0.035)\end{array}$ & $\begin{array}{l}-0.107 * * \\
(0.05)\end{array}$ & $\begin{array}{l}-0.045^{* *} \\
(0.018)\end{array}$ & $\begin{array}{l}-0.037 * * \\
(0.015)\end{array}$ \\
\hline Observations & 340 & 340 & 340 & 340 & 130 \\
\hline $\mathrm{R} 2$ & $0.976 ; 0.919$ & $0.976 ; 0.918$ & $0.976 ; 0.905$ & $0.976 ; 0.872$ & $0.993 ; 0.978$ \\
\hline
\end{tabular}

Note: All regressions include province-specific fixed effects and year effects. The implied effect of the tax rate is the elasticity of the hourly wage rate with respect to the CIT rate, calculated as the elasticity of K/L with respect to the CIT rate times the elasticity of wages with respect to K/L. Robust standard errors in parentheses. Significance levels are indicated by $* * *$ for one per cent, ** for five per cent, and * for 10 per cent. 
Table 4: Corporate Income Tax Incidence on Wages (2014 \$C)

\begin{tabular}{l|l|l|}
\hline \hline Province & Constant CIT Base $^{\mathrm{a}}$ & Responsive CIT Base $^{\mathrm{b}}$ \\
\hline British Columbia & 1.34 & 2.25 \\
Alberta & 0.96 & 1.52 \\
Saskatchewan & 1.12 & 2.01 \\
Manitoba & 1.52 & 2.72 \\
Ontario & 1.14 & 1.97 \\
Quebec & 0.98 & 1.74 \\
New Brunswick & 1.74 & 3.12 \\
Nova Scotia & 1.18 & 2.86 \\
Prince Edward Island & 1.59 & 3.85 \\
Newfoundland and Labrador & 0.95 & 1.95 \\
\hline \hline
\end{tabular}

Source: Authors' computations based on the estimated wage elasticity with respect to the statutory corporate income tax rate (column (3) of Table (3)) and provincial corporate income tax revenue and wage income data for 2014 . The figures show the dollar amount by which wages decrease due to a $\$ 1$ increase in corporate income tax liability.

a: Assumes the CIT base remains constant in response to an increase in the tax rate.

b: Assumes the CIT base shrinks in response to an increase in the tax rate, using semi-elasticity estimates from Dahlby and Ferede (2012) to calculate the shrinkage in the tax base. 
Table 5: Robustness Checks (3SLS)

\begin{tabular}{|c|c|c|c|c|}
\hline Robustness check & & $\begin{array}{l}1) \\
\text { Coeff. on CIT rate (K/L Regr.) }\end{array}$ & $\begin{array}{l}\text { (2) } \\
\text { Coeff. on K/L (Wage Regr.) }\end{array}$ & $\begin{array}{l}\text { (3) } \\
\text { Implied effect of CIT on Wage }\end{array}$ \\
\hline 1 & Average CIT rate of previous 4 years & $\begin{array}{l}-0.240^{* *} \\
(0.105)\end{array}$ & $\begin{array}{l}0.456^{* * *} \\
(0.043)\end{array}$ & $\begin{array}{l}-0.110 * * * \\
(0.048)\end{array}$ \\
\hline 2 & Average CIT rate of previous 3 years & $\begin{array}{l}-0.244 * * \\
(0.102)\end{array}$ & $\begin{array}{l}0.455^{* * * *} \\
(0.043)\end{array}$ & $\begin{array}{l}-0.111 * * \\
(0.046)\end{array}$ \\
\hline 3 & Five-year effects of CIT & $\begin{array}{l}-0.265 * * \\
(0.115)\end{array}$ & $\begin{array}{l}0.431 * * * \\
(0.042)\end{array}$ & $\begin{array}{l}-0.114 * * \\
(0.05)\end{array}$ \\
\hline 4 & Four-year effects of CIT ${ }^{\mathrm{a}}$ & $\begin{array}{l}-0.263^{* *} \\
(0.11)\end{array}$ & $\begin{array}{l}0.434 * * * \\
(0.043)\end{array}$ & $\begin{array}{l}-0.114 * * \\
(0.048)\end{array}$ \\
\hline 5 & Three-year effects of CIT ${ }^{\mathrm{a}}$ & $\begin{array}{l}-0.262^{* *} \\
(0.105)\end{array}$ & $\begin{array}{l}0.442 * * * \\
(0.043)\end{array}$ & $\begin{array}{l}-0.116^{* *} \\
(0.047)\end{array}$ \\
\hline 6 & Using total capital stock & $\begin{array}{l}-0.174 * * * \\
(0.062)\end{array}$ & $\begin{array}{l}0.861 * * * \\
(0.103)\end{array}$ & $\begin{array}{l}-0.150 * * * \\
(0.054)\end{array}$ \\
\hline 7 & Including overtime & $\begin{array}{l}-0.240^{* *} \\
(0.11)\end{array}$ & $\begin{array}{l}0.477 * * * \\
(0.043)\end{array}$ & $\begin{array}{l}-0.114 * * \\
(0.052)\end{array}$ \\
\hline 8 & Including relative price of capital & $\begin{array}{l}-0.245^{* *} \\
(0.111)\end{array}$ & $\begin{array}{l}0.464 * * * \\
(0.043)\end{array}$ & $\begin{array}{l}-0.114 * * \\
(0.051)\end{array}$ \\
\hline $9^{b}$ & $\begin{array}{l}\text { Provincial CIT } \\
\text { Federal CIT }\end{array}$ & $\begin{array}{l}-0.121 * * * \\
(0.026) \\
-0.092 * * * \\
(0.03)\end{array}$ & $\begin{array}{l}0.429 * * * \\
(0.071)\end{array}$ & $\begin{array}{l}-0.052 * * * \\
(0.014) \\
-0.040^{* * *} \\
(0.015)\end{array}$ \\
\hline
\end{tabular}

Note: The robustness checks are based on our preferred regression of column (3) of Table 3. Standard errors in parentheses. Significance levels are indicated by $* * *$ for one per cent, ** for five per cent, and * for 10 per cent. All regressions include fixed provincial and year effects.

a: The coefficients on the CIT rate are obtained by summing the coefficient estimates of the contemporaneous tax rate and all relevant lagged values of the tax rate that are included as explanatory variables.

b: This regression does not include year effects since the federal CIT rate changes only over time and is common across provinces. 
Table 6: Data Appendix

\begin{tabular}{l|l|l|}
\hline \hline Variable & Definition & Source \\
\hline CIT & $\begin{array}{l}\text { Provincial and federal combined top statutory corporate income } \\
\text { tax rate }\end{array}$ & Finances of the Nation (various issues) \\
\hline ATR & $\begin{array}{l}\text { Effective average corporate income tax rate. Calculated as } \\
\text { provincial corporate income tax revenue divided by corporate } \\
\text { income tax base }\end{array}$ & $\begin{array}{l}\text { Finance Canada (corporate tax revenue and base data used for al- } \\
\text { location of equalization grants (1976-2008)) and provincial pub- } \\
\text { lic accounts (2009-2014) }\end{array}$ \\
\hline Wage & Average hourly earnings (all industries) excluding overtime & CANSIM 281-0008 and CANSIM 281-0030 \\
\hline Other CIT & $\begin{array}{l}\text { Weighted average (weighted by GDP) CIT rate of other } \\
\text { provinces }\end{array}$ & Finances of the Nation (CIT) and CANSIM 384-0038 (GDP) \\
\hline K/L) & $\begin{array}{l}\text { Aggregate total non-residential capital stock (in 2007 dollars) to } \\
\text { labour ratio }\end{array}$ & CANSIM 031-0007 (capital) and CANSIM 282-0002 (labour) \\
\hline Average labour growth & Average growth rate of labour over the previous five years & CANSIM 282-0002 (labour) \\
\hline Average GDP growth & Average growth rate of real GDP over the previous five years & CANSIM 384-0038 (real GDP) \\
\hline GDP per capita & Provincial GDP per capita (in 2007 dollars) & $\begin{array}{l}\text { CANSIM 384-0038 (real GDP) and CANSIM 51-0001 (popula- } \\
\text { tion) }\end{array}$ \\
\hline Unemployment & Provincial unemployment rate & CANSIM 282-0002 \\
\hline Union & Share of workers who are unionized & $\begin{array}{l}\text { CANSIM 279-0025 (1976-1995) and CANSIM 282-0220 } \\
\text { (1997-2014) }\end{array}$ \\
\hline Openness & Provincial trade to GDP ratio & CANSIM 384-0038 \\
\hline Public wages & $\begin{array}{l}\text { Average monthly wages \& salaries for workers in the public sec- } \\
\text { tor. Obtained by dividing monthly wages and salaries in the pub- } \\
\text { lic sector by public sector employment }\end{array}$ & \\
\hline University & Share of the population with a university degree & $\begin{array}{l}\text { Census data (1981, 1986, \& 1991) } \\
(1990-2014)\end{array}$ \\
\hline \hline
\end{tabular}

Note: Nominal wages are converted to real wages using CPI (2007=100) (CANSIM 326-0021).

a: The CIT base for 2009-2014 is obtained through extrapolation using the growth rate of corporate net operating surplus data (CANSIM 584-0037).

b: The two data series may not be directly comparable, however the trends are similar.

c: The series is updated for 2013 and 2014 using the growth rate of total compensation per hour for the government sector (CANSIM 3830030).

d: Data between census years are based on extrapolation assuming a constant growth rate. 